\title{
COASTAL TANZANIA, A NEW HOME TO THE LIVING COELACANTH: AN OCEANOGRAPHIC ANALYSIS
}

\author{
N Nyandwi \\ University of Dar es salaam, Institute of Marine Sciences, P. O. Box 668, Zanzibar, Tanzania. \\ Nyandwi@ims.udsm.ac.tz
}

\begin{abstract}
Coelacanth is no longer a new fish in Tanzania. After it was first discovered in September 2003 off Kilwa Masoko in southern Tanzania and with awareness campaigns, fishermen have reported further landings since, mostly in Tanga, northern Tanzania at Kigombe village. Analysis of habitat conditions suitable for the coelacanth indicates that the oceanography may just be right for the fish to have a permanent residence as opposed to the theory of drifters from a natural home elsewhere. At one time three specimens were captured together in the same net indicating that they formed a group. Oceanographic studies of the habitat in Tanga suggest that there could well be a resident population supported by existence of sharp slopes and steps. Caves in which the fish hides might be present at about $150 \mathrm{~m}$ depth where suitable temperatures of about $21^{\circ} \mathrm{C}$ are found.
\end{abstract}

\section{INTRODUCTION}

The coelacanth is member of a group of fish known as the Crossopterygii, which became extinct towards the end of the Cretaceous some 65-70 ma. They are well known from fossil records dating as far back as the Devonian times about some 410 ma. In 1938 the fish was rediscovered after it was landed at East London in South Africa by a trawl boat (Smith 1939). Scientists embarked on a search for the next specimen, at one point offering a reward of British Pounds 100, and a second one was found in the Comoro Islands in 1952. Since then few hundred specimen have been caught in these islands and not anywhere else until 1991 when one was found at Pebane in Mozambique. The overwhelming number of specimens caught in the Comoros made scientists believe the islands were the true home while other captures constituted drifters (e.g. Balon et al. 1988, Bruton 1989, Bruton et al. 1992, Hissmann et al. 1998). Other incidents and in areas afar began to be reported i.e. Mozambique, Indonesia, South Africa, Kenya and Tanzania (Table 1). The discovery of more than one individual alive in Sodwana Bay, South Africa in 2000 (Venter et al. 2000) prompted further search and using submersibles more specimens have been observed in canyons. A debate still rages on as to which is the true home. Genetic studies suggest that the fish caught in Mozambique and Comoro belonged to the same population (Schliewen et al. 1993). After the discovery of the fish in Indonesia, genetic studies though not very conclusive seem to suggest that the Indonesian population separated from the one in Comoro (Pouyaud et al. 1999, Holder et al. 1999). It appears now as if the fish is widely distributed along the shelf of the western Indian Ocean. But since it is not widely found, it is significant to document each capture. This paper describes chronology of the initial captures in Tanzania and discusses the habitat suitability. 
Nyandwi-Coastal Tanzania; A new home to the living Colelacanth ...

Table 1: Reported first capture of the living coelacanth. The question mark indicates unknown.

\begin{tabular}{lllll}
\hline Year & Landing & Bottom type & Fishery type & Vessel Name \\
\hline 1938 & East London, S. Africa & Rocky & Trawl & Nerine \\
1952 & Comoro islands & Volcanic slopes & Lining & $?$ \\
1991 & Pebane, Mozambique & Sandy & Trawl & Vega \\
1995 & Toliara, Madagascar & Sandy & Shark net & $?$ \\
1997 & Solaweshi, Indonesia & $?$ & Shark nets & $?$ \\
2001 & Malindi, Kenya & $?$ & Trawl & MV Venture \\
2003 & Kilwa Masoko, Tanzania & $?$ & Shark net & $?$ \\
\hline
\end{tabular}

\section{COELACANTH OCCURRENCE IN}

\section{TANZANIA}

Until September 2003, living coelacanth was not known to any in Tanzania. It was in 2002 and early 2003 that the South African Institute for Aquatic Biodiversity (SAIAB) contacted the Tanzania Fisheries Research Institute (TAFIRI) in Tanzania to embark on coelacanth research. The programme's education component emphasises on public awareness of the fish for conservation. As such, when the fish was caught in southern Tanzania and brought for sale at the local market, a tourist managed to recognise it and information was relayed for the specimen to be collected. The fisherman received cash reward for handing in the specimen. In March 2004, a second specimen was landed by fishermen from the same fishing area, around the small island of Songo Mnara, off Kilwa Masoko (Fig. 1).

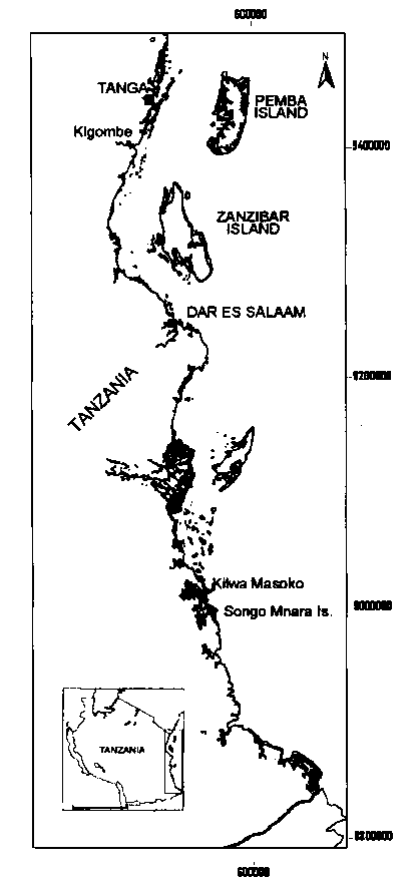

Figure 1: Location of coelacanth captures along the coast of Tanzania 
During August and September 2004 six more specimens were caught off Kigombe village in Tanga, northern Tanzania. In the first instance three specimens were caught in one gill net. In September 2004, another specimen was recovered from the same fishing site as the first one in Kilwa. By the end of 2004, reported captures in Tanzanian waters reached 24. Nowhere else in the region except the Comoro Islands have so many specimens been caught and this raises concern.

\section{COELACANTH HABITAT}

A survey of the catch site off the village of Kigombe in Tanga was made by a team of scientists accompanied by the fishermen who caught the fish. The capture area is located among reefs with bottom depth of $70 \mathrm{~m}$. Scuba diving during the month of
August 2004 on the reef slope recorded surface temperature of $27^{\circ} \mathrm{C}$, bottom temperature of about $23^{\circ} \mathrm{C}$ at $28 \mathrm{~m}$ and a swift current of $0.5-1 \mathrm{~ms}^{-1}$ was observed. The offshore area off reefs seemed to be characterised by an alternation of submarine terraces and steep drop-offs between $70 \mathrm{~m}$ and $140 \mathrm{~m}$. An oceanographic section (for conductivity, temperature, depth measurements) by the Research Vessel FRS Algoa, a few kilometers to the south of the site, starting at a depth of $138 \mathrm{~m}$ about 15 $\mathrm{km}$ offshore, shows that the depth drops rapidly to about $700 \mathrm{~m}$ just some $45 \mathrm{~km}$ offshore (Fig. 2). The temperature at $150 \mathrm{~m}$ depth was about $21^{\circ} \mathrm{C}$ (Fig. 2). A similar sharp drop of the shelf depth characterizes the capture site off Songo Mnara, in the south, although the current and wave regime is much stronger.

\section{Pemba Island Transect}
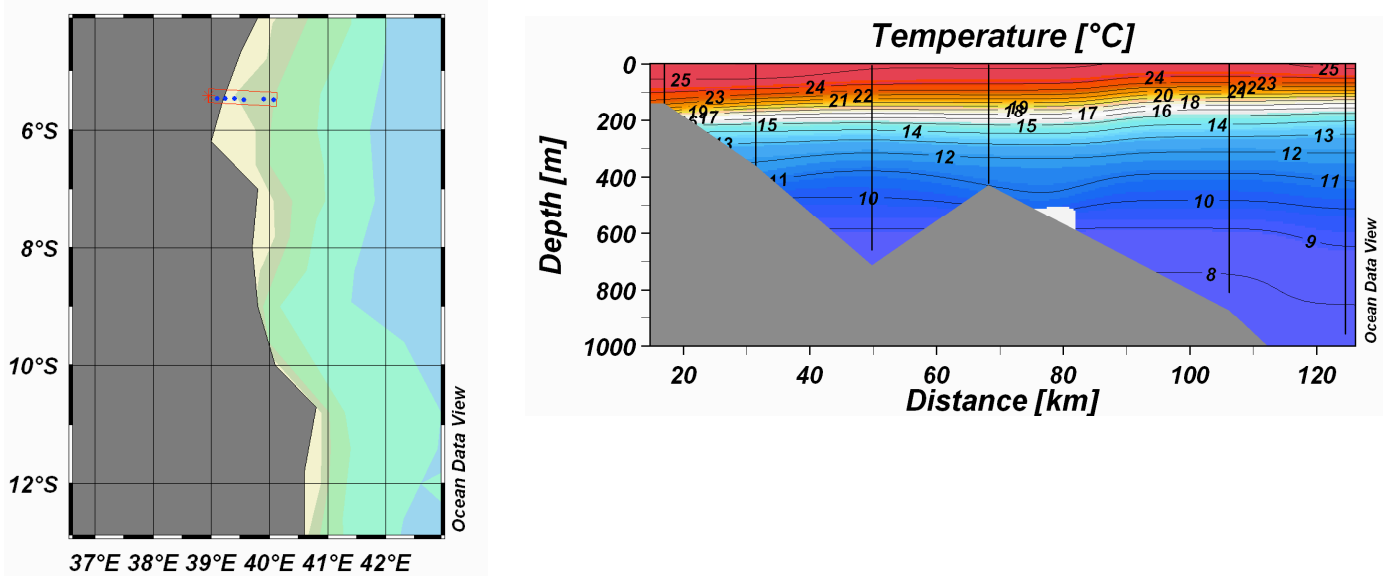

Figure 2: Oceanographic conditions along a CTD line across the coelacanth catch site.

\section{DISCUSSION}

The debate as to which is the home to the coelacanth was initially driven by the number of capture incidents but now it seems to hinge on two conditions namely, a suitable temperature range (between 16 and $23^{\circ} \mathrm{C}$ ) and favourable geomorphology (availability of caves/overhangs in steep slopes). Observational oceanography suggests that the fish's habitat is more temperature controlled. In Sodwana Bay, the fish has been found to hide in caves within canyons at a depth of between $104 \mathrm{~m}$ and $148 \mathrm{~m}$ where the temperature range is 16 - 
$21^{\circ} \mathrm{C}$, whereas submersible dives in the Comoros found it in overhangs along steep volcanic slopes at depths of $250-300 \mathrm{~m}$ with a temperature range of $15-20^{\circ} \mathrm{C}$ and a maximum of $22.8^{\circ} \mathrm{C}$. (Fricke and Plante 1988, Fricke et al. 1991, Fricke and Hissmann 2000). In Indonesia, submersible dives found the fish in caves within steep carbonate rocks (Fricke et al. 1991, Fricke and Hissmann 2000, Fricke et al. 2000). It appears that the fish lives within a small temperature range of between $15-23^{\circ} \mathrm{C}$ (Fricke et al. 1991, Fricke and Hissmann 2000), which seems to control the depth at which the fish is found. Such a temperature range will be found at greater depths in equatorial than in tropical waters.

The capture of the fish at depths shallower than $200 \mathrm{~m}$ in Tanzania may be explained by the occurrence of lower temperatures during the SE monsoon period (July September). During this period, maximum surface temperature drops to around $26^{\circ} \mathrm{C}$ (Newell 1957) decreasing rapidly to about $20^{\circ} \mathrm{C}$ at about $200 \mathrm{~m}$ depth. This temperature range is within known suitable temperature range for the coelacanth. Sharp drop-offs and submarine terraces off reefs present suitable setting for occurrence of caves and overhangs in which the fish hides. During hunting, mainly at night, the fish is known to leave the caves to distant and shallower areas and hence the accidental captures in the gill nets (Fricke and Hissmann 1994, Hissmann et al. 1998, Fricke and Hissmann 2000).

The fact that at one time three specimens were caught in one net suggests that they belong to a population, which may be resident. Individuals of a population are known to move in smaller numbers or individually in search of food (Fricke and Hissmann 1994, Hissmann et al. 1998, Fricke and Hissmann 2000). The capture of the fish off the Tanzania coast is most likely related to the recent introduction of gill net fishery. The nets are set at depths between 50 and $150 \mathrm{~m}$.
The coelacanth is protected under the Convention on International Trade in Endangered Species (CITES) and the recent captures raise concern as to what protective measures should be taken. Already there are suggestions in the media to ban gill net fishery in the area. However, it is still probable that the specimens could just have been drifters from the proven population in the Comoro. It is thus important to undertake more studies, especially with submersibles to prove existence of a resident population so as to come up with suggestions for protection measures.

\section{ACKNOWLEDGEMENT}

The African Coelacanth Ecosystem Programme (ACEP) is acknowledged for the financial and technical support.

\section{REFERENCES}

Balon EK, Bruton MN and Fricke H 1988 A fiftieth anniversary reflection on the living coelacanth, Latimeria chalumnae: some new interpretations of its natural history and conservation status. Env. Biol. Fish. 23(4): 241-279

Bruton MN 1989 The living coelacanth fifty years later. Transactions of the Royal Society of South Africa 47(1): 19-28

Bruton MN, Cabral AJP and Fricke H 1992 First capture of a coelacanth, Latimeria chalumnae (Pisces, Latimeriidae), off Mozambique. S. Afr. J. of Sci. 88: 225227

Fricke HW and Hissmann K 1994 Home range and migrations of the living coelacanth Latimeria chalumnae. Mar. Biol. 120: 171-180

Fricke HW and Hissmann K 2000 Feeding ecology and evolutionary survival of the living coelacanth Latimeria Chalumnae. Mar. Biol., 136: 379-386

Fricke HW and Plante R 1988 Habitat requirements of the living coelacanth Latimeria chalumnae at Grande Comore, Indian Ocean. Naturwiss. 75:149 151.

Fricke HW, Hissmann K, Schauer J, Reinicke $\mathrm{O}$, Kasang $\mathrm{L}$ and Plante $\mathrm{R}$ 
1991 Habitat and population size of the living coelacanth Latimeria chalumnae. Env. Biol. Fish. 32:287-300.

Fricke H, Hissmann K, Schauer J, Erdmann M, Moosa MK and Plante R 2000 Biogeography of the Indonesian coelacanths. Nature 403: 38.

Hissmann K, Fricke H and Schauer J 1998 Population Monitoring of the Coelacanth (Latimeria chalumnae). Cons. Biol. 12 (4): 759

Holder MT, Erdmann MV, Wilcox TP, Caldwell RL and Hillis DM 1999

Two living species of coelacanths. Proc. Nat. Acad. of Sci. 96: 12616-12620.

Newell BS 1957 A Preliminary survey of the hydrography of the British East African Coastal Waters. Colonial Office
Fishery Publication, 9. Her Majesty Stationery Office, London, 21 pp

Pouyaud L, Wirjoatmodjo S, Rachmatika I, Tjakrawidjaja A, Hadiaty $\mathrm{R}$ and Hadie W 1999 A new species of coelacanth. Comptes Rendus 322 (4): 261-267.

Schliewen U, Fricke H, Schartl M, Epplen JT and PaeaeboS 1993 Which home for coelacanth? Nature 363: 405.

Smith JLB 1939 A living fish of Mesozoic type. Nature 140: 455.

Venter P, Timm P, Gunn G, le Roux E, Serfontein C, Smith P, Smith E, Bensch M, Harding D and Heemstra P 2000 Discovery of a viable population of coelacanths (Latimeria chalumnae Smith, 1939) at Sodwana Bay, South Africa. S. Afr. J. Sci. 96: 567-568. 